\title{
RNA-seq Analysis of Salt-Stressed Versus Non Salt-Stressed Transcriptomes of Chenopodium quinoa Landrace R49
}

\author{
Karina B. Ruiz ${ }^{1, *,+(\mathbb{D}) \text {, Jonathan Maldonado }}{ }^{2,+} \mathbb{D}$, Stefania Biondi ${ }^{3} \mathbb{D}$ and Herman Silva ${ }^{2, *}(\mathbb{D}$ \\ 1 Departamento de Agricultura del Desierto, Facultad de Recursos Naturales, Universidad Arturo Prat, \\ Campus Huayquique, Av. Arturo Prat S/N, Iquique 1100000, Chile \\ 2 Departamento de Producción Agrícola, Laboratorio de Genómica Funcional y Bioinformática, \\ Universidad de Chile, Av. Santa Rosa 11315, Santiago 8820808, Chile; jomaldon@gmail.com \\ 3 Dipartimento di Scienze Biologiche, Geologiche e Ambientali, Università di Bologna, Via Irnerio 42, \\ 40126 Bologna, Italy; stefania.biondi@unibo.it \\ * Correspondence: karuiz@unap.cl (K.B.R.); hesilva@uchile.cl (H.S.); Tel.: +56-572526590 (K.B.R.); \\ +56-229785726 (H.S.) \\ + These authors have equally contributed to this paper.
}

Received: 28 October 2019; Accepted: 7 December 2019; Published: 16 December 2019

\begin{abstract}
Quinoa (Chenopodium quinoa Willd.), a model halophytic crop species, was used to shed light on salt tolerance mechanisms at the transcriptomic level. An RNA-sequencing analysis of genotype R49 at an early vegetative stage was performed by Illumina paired-ends method comparing high salinity and control conditions in a time-course pot experiment. Genome-wide transcriptional salt-induced changes and expression profiling of relevant salt-responsive genes in plants treated or not with $300 \mathrm{mM} \mathrm{NaCl}$ were analyzed after $1 \mathrm{~h}$ and 5 days. We obtained up to 49 million pairs of short reads with an average length of $101 \mathrm{bp}$, identifying a total of 2416 differentially expressed genes (DEGs) based on the treatment and time of sampling. In salt-treated vs. control plants, the total number of up-regulated and down-regulated genes was 945 and 1471, respectively. The number of DEGs was higher at 5 days than at $1 \mathrm{~h}$ after salt treatment, as reflected in the number of transcription factors, which increased with time. We report a strong transcriptional reprogramming of genes involved in biological processes like oxidation-reduction, response to stress and response to abscisic acid (ABA), and cell wall organization. Transcript analyses by real-time RT- qPCR supported the RNA-seq results and shed light on the contribution of roots and shoots to the overall transcriptional response. In addition, it revealed a time-dependent response in the expression of the analyzed DEGs, including a quick (within $1 \mathrm{~h}$ ) response for some genes, suggesting a "stress-anticipatory preparedness" in this highly salt-tolerant genotype.
\end{abstract}

Keywords: ethylene-related genes; gene expression; halotolerant crop; salinity; transcriptome

\section{Introduction}

Quinoa (Chenopodium quinoa Willd.) is an ancient crop native to South America (around Lake Titicaca in Bolivia and Peru) that is receiving attention worldwide due to its high nutritional value [1] and content in health-promoting compounds [2]. In addition, it is highly resistant to environmental stresses [3,4]. In 2013, the United Nations Food and Agriculture Organization (FAO) recognized quinoa as a key crop for food security and sustainability under a scenario of global change $[5,6]$. Thus, interest in the crop is still growing, mainly due to increasing water scarcity and soil salinization on a global scale. The production of quinoa in Chile is low as compared to top quinoa-producing countries, namely Peru and Bolivia. This is in part due to less competitiveness in crop management and market 
access, but also to the limited knowledge of growers and consumers about Chilean quinoa grain and its particular nutritional characteristics [7].

Despite a wealth of information regarding salinity responses and possible tolerance mechanisms in quinoa [8,9], studies at the transcriptional level are still relatively scarce. Changes in transcript abundance of the ion transporter CqSOS1 under $\mathrm{NaCl}$ treatment were reported by Maughan et al. [10]; subsequently, the same gene and another gene ( $C q N H X)$ involved in ion homeostasis were comparatively analyzed in several Chilean landraces originating from contrasting habitats [11]. More recently, the expression of 24 different genes belonging to a number of categories [growth-related, ion homeostasis, transcription factors, abscisic acid (ABA) perception, and biosynthesis, and polyamine biosynthesis], and other salt-responsive genes were analyzed under salt stress $(300 \mathrm{mM} \mathrm{NaCl})$ in two Chilean landraces belonging to different ecotypes, i.e., the "salares" and the "coastal-lowlands" [8]. Today, the availability of the quinoa genome and high-throughput genomic methods have provided new tools for addressing the complexity associated with stress tolerance in this species $[12,13]$. To identify candidate salt tolerance genes, Schmöckel et al. [9] focused their study on transmembrane proteins, using a multifaceted approach integrating RNA-seq with single nucleotide polymorphism (SNP) analyses. They identified 219 candidate genes having more than one predicted transmembrane domain that responded to salinity and was specific to or over-represented in quinoa as compared to other Amaranthaceae species.

We have chosen the drought- and salt-tolerant Chilean landrace R49 for better understanding its salt tolerance mechanisms through exploring the plant's transcriptome under saline and non-saline conditions. This landrace belongs to the "salares" ecotype [14] and originates from the arid northern part of the country (Chilean altiplano). Recently, a genome-wide transcriptomic study by RNA-seq was carried out in R49 under drought stress [15]. In order to complement current knowledge on stress-induced transcriptional responses in this quinoa genotype, the present RNA-seq analysis was conducted after exposing R49 plants to high salinity. The novelty of the present work consists in the fact that this is the first time that a full transcriptomic analysis is conducted in a quinoa genotype belonging to the "salares" ecotype under saline conditions. The transcriptomic analysis conducted by Schmöckel et al. [9] was aimed at identifying transmembrane proteins associated with salinity tolerance in the "coastal" ecotype reference genome P614886 [13]. Moreover, as opposed to similar studies on quinoa conducted previously $[9,15,16]$, we analyzed the transcriptome at two time-points $(1 \mathrm{~h}$ and $120 \mathrm{~h}$ ); in particular, the short-term salinity-induced transcriptional response after $1 \mathrm{~h}$ of exposure to $300 \mathrm{mM} \mathrm{NaCl}$ has not been previously considered. In spite of its high salt tolerance, early vegetative growth stages in quinoa are quite sensitive to stress conditions $[8,17]$, thus the study was performed on seedlings.

Based on our RNA-seq results and on previous studies regarding genes that are known to be induced by salinity in glycophytic and halophytic model species [8,18-20], 10 genes were selected for expression profiling by real-time RT- qPCR analysis. The analyzed genes fall in three main categories: (i) stress-related genes that have been previously indicated as markers in salt-tolerant species, i.e., carotenoid cleavage dioxygenase 4 (CarD4), lipoxygenase (LOX), leucoanthocyanidin dioxygenase (LDOX), rd22-like protein (RD22), and 8-1-pyrroline 5-carboxylase synthetase (P5CS); (ii) ethylene (ET) perception-related (Ethylene Receptor1, ETR1) and biosynthetic (1-aminocyclopropane-1-carboxylic acid synthase, ACS; 1-aminocyclopropane-1-carboxylic acid synthase 2, ACS2; 1-aminocyclopropane-1-carboxylic acid oxidase-like protein, ACO1) genes, and (iii) a growth-related gene, $\beta$-expansin ( $\beta$-EXP). Results shed new light on salt tolerance mechanisms at the molecular level in a highly halotolerant crop species.

\section{Materials and Methods}

\subsection{Plant Material}

Seeds of Chenopodium quinoa landrace R49 were provided by the seed bank of INIA-Vicuña, Chile. Approximately 200 seeds were pre-sterilized in ethanol/water $70 \%$ (v/v) for $5 \mathrm{~min}$, followed by $10 \%$ 
hypochlorite commercial solution for $5 \mathrm{~min}$ and then subjected to several rinses in autoclaved water. The seeds were vernalized for $12 \mathrm{~h}$ at $4{ }^{\circ} \mathrm{C}$ and then directly sown in plastic pots containing perlite. They were periodically irrigated with water supplemented with fertilizer (N:P:K 10:10:27; $0.4 \mathrm{~g} \mathrm{~L}^{-1}$; Phostrogen Bayer Garden, Cambridge, UK) and grown under growth chamber conditions (photoperiod $16 \mathrm{~h} \mathrm{light} / 8 \mathrm{~h}$ dark at a temperature of $21^{\circ} \mathrm{C}$ ).

When seedlings had 6 fully-expanded leaves (ca. 40-days old), 108 individuals were selected and separated into two independent experiments with 54 individuals each. Salt stress was imposed by irrigating with Phostrogen solution added with $300 \mathrm{mM} \mathrm{NaCl}$ (treated plants) or not (control plants; $0 \mathrm{mM} \mathrm{NaCl}$ ). Control and $\mathrm{NaCl}$-treated plants ( 27 individuals each) were collected at 3 different times: 1,24 , and $120 \mathrm{~h}$ after treatment (AT). At each time point, a total of 9 individuals were subdivided into 3 biological replicates (i.e., each biological replicate was composed of 3 plants that were pooled together), from which roots and shoots were collected separately, weighed, and frozen in liquid nitrogen (Figure 1). Dry biomass of roots and shoots was measured, indicating that the 2 independent experiments gave similar results. Therefore, for the transcriptomic analysis, we worked with material from a single experiment. Dry weight (DW) was determined in freeze-dried samples.

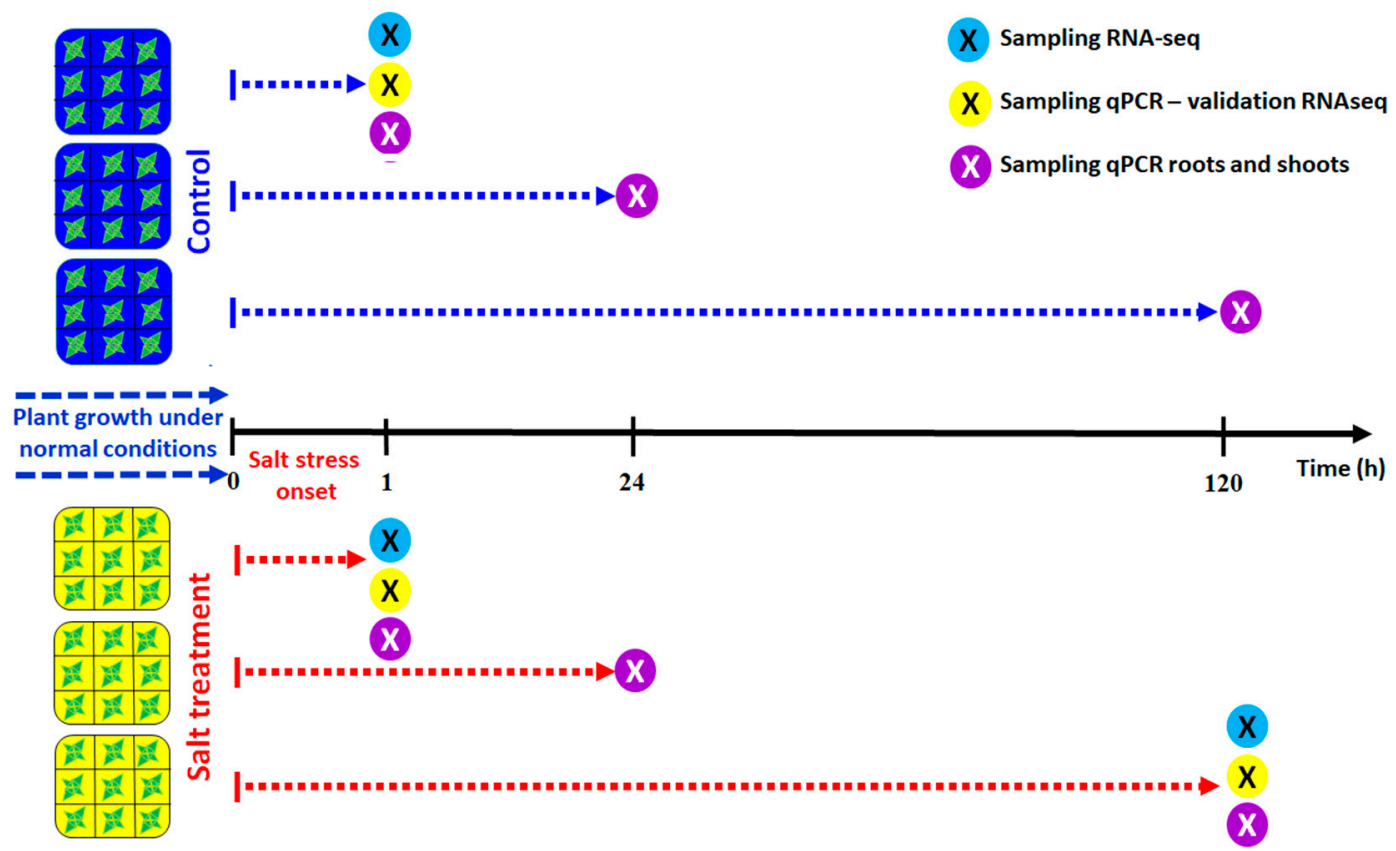

Figure 1. Experimental design and sampling times from the start of salt treatment for RNA-seq and real-time RT-qPCR analyses.

\subsection{RNA Extraction}

Total RNA was extracted according to Chang et al. [21]. RNA yield and purity were checked by means of UV absorption spectra, whereas RNA integrity was determined by electrophoresis on an agarose gel. The concentration of the RNA extracted was evaluated using the NanoDrop spectrophotometer (Thermo Scientific-1000, Thermo Fisher Scientific, Wilmington, DE, USA). DNA was removed using the TURBO DNA-free ${ }^{\mathrm{TM}}$ kit (Life Technologies, Carlsbad, CA, USA) from $10 \mu \mathrm{g}$ aliquots of total RNA, allowing us to proceed with a high-quality RNA.

RNA was extracted separately from roots and shoots (using 3-5 samples of $0.1 \mathrm{~g}$ fresh weight each). For each biological replicate (i.e., group of 3 plants per treatment and per time point), $3.0 \mu \mathrm{g}$ of RNA extracted from roots and $3.0 \mu \mathrm{g}$ from shoots, were pooled to obtain $6 \mu \mathrm{g}$ of total RNA (roots + shoots; $\mathrm{R}+\mathrm{S}$ ). From this $6.0 \mu \mathrm{g}$, $3.0 \mu \mathrm{g}$ was taken from each biological replicate and combined (giving a total of $9.0 \mu \mathrm{g}$ ) for the RNA-seq analysis; thus, the RNA represented the average of 9 individuals. For the validation of some DEGs by real-time RT-qPCR analysis, $3.0 \mu \mathrm{g}$ from each biological replicate (roots + 
shoots; $R+S)$ were used for cDNA synthesis $(n=3)$. The specific contribution of each organ was also studied by real-time RT-qPCR analysis. In this case, the cDNA was synthesized from $3.0 \mu \mathrm{g}$ total RNA extracted from roots and shoots separately and for each of the 3 biological replicates $(n=3)$ (Figure 2).

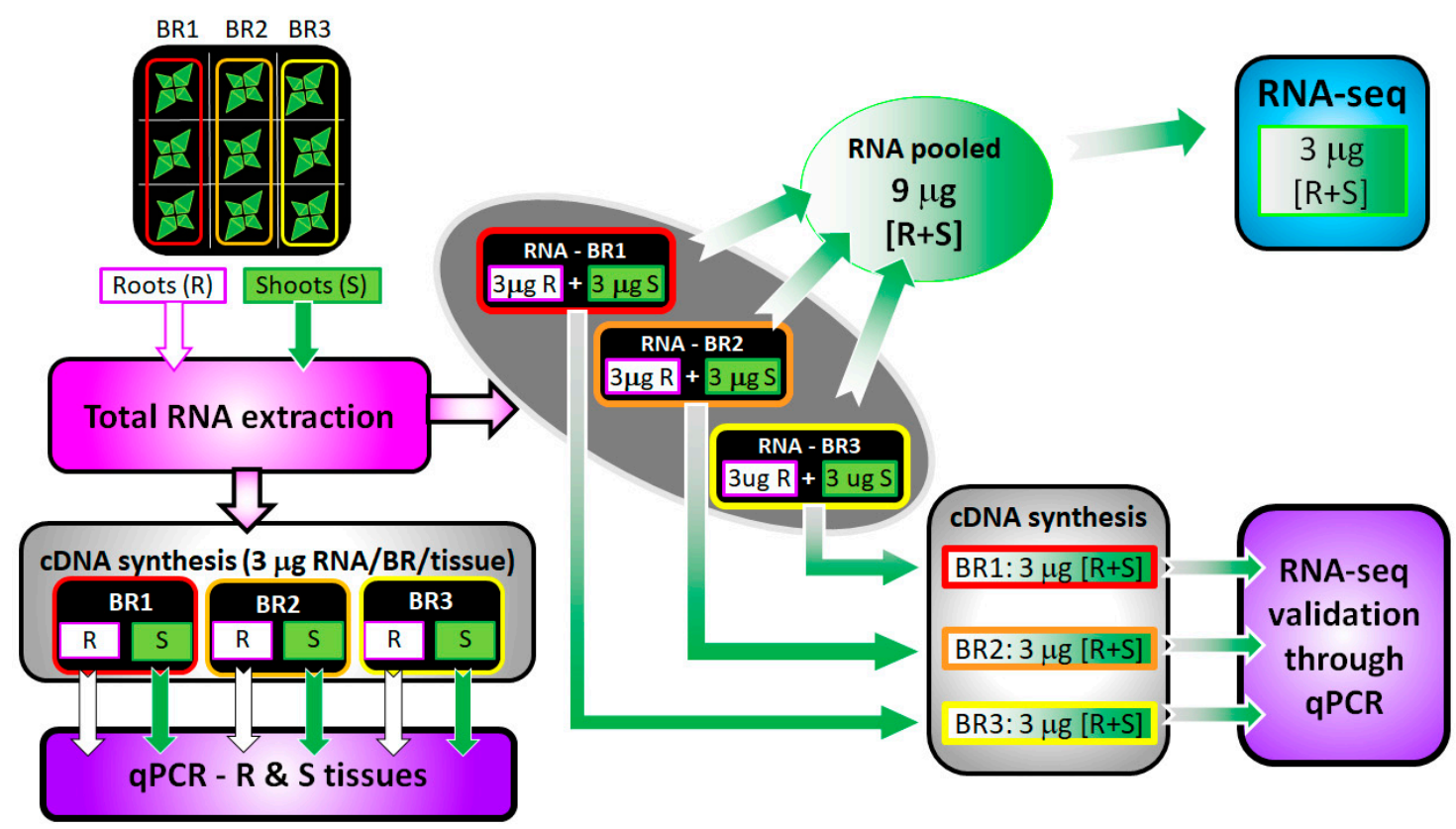

Figure 2. Scheme of RNA extraction from the roots (white square) and shoots (green square) and their utilization, either pooled or not, for RNA-seq and real-time RT-qPCR studies. BR: Biological replicate;

R: Roots; S: Shoots. See Material and Methods, Sections 2.1 and 2.2.

\subsection{Library Preparation and RNA Sequencing}

The following 3 samples were prepared for the transcriptomic analysis: (i) roots and shoots under control conditions, collected $1 \mathrm{~h}$ after the salt treatment was initiated in salt-treated samples; (ii) roots and shoots from plants irrigated with $300 \mathrm{mM} \mathrm{NaCl}$ and collected $1 \mathrm{~h} \mathrm{AT}$; (iii) roots and shoots from plants irrigated with $300 \mathrm{mM} \mathrm{NaCl}$ and collected $120 \mathrm{~h}$ AT. For RNA sequencing, three samples of $3.0 \mu \mathrm{g}$ each of RNA purified from roots and shoots of the above-described samples were mixed together. RNA samples with integrity values $\geq 7.0$ were used for library preparation. The RNA library was prepared using the Illumina TruSeq protocol (Macrogen, Seoul, South Korea) after constructing a TruSeq mRNA library for paired-end application with an insertion length of $550 \mathrm{bp}$. The transcriptome sequencing for each sample was carried out with the Illumina HiSeq2000 platform (Illumina, San Diego, CA, USA).

\subsection{RNA Sequence Analysis}

Trimming and mapping of the sequence reads were performed using the CLC Genome Workbench version 10.1.1 (CLC Bio: CLC genomics workbench [http://www.clcbio.com]). Trimming was based on the following parameters: $Q \geq 20$; no more than two ambiguities; final read length $\geq 50 \mathrm{bp}$. Then, reads of each sequenced library were mapped against the predicted coding sequences of the C. quinoa genome $(44,776$ predicted genes, [13]) using the following parameters: Similarity $=0.9$; length fraction $=0.6$; insertion/deletion cost $=3$; mismatch cost $=3$, and unspecific match limit $=10$. Relative transcript abundance was obtained as the unique number of reads mapped to each gene. The transcript abundance in these datasets was compared using a Z-Test [22]. This test compares counts by considering the proportions that make up the total sum of counts in each sample, correcting the data for sample size. For visual inspection, original over/under-represented values were transformed by the Log10 method and then normalized using the quantile method $[23,24]$. 


\subsection{Functional Annotation of Reference Transcriptome and Gene Ontology Over-Representation Analysis}

Functional annotation of $C$. quinoa reference transcripts $[13,15]$ was performed by BLAST2GO software [25] as a plugin of the CLC Genomics Workbench software version 10.1.1 (plugin version 1.1.0). First, a BLASTx search was performed against the NCBI NR database [26] with an e-value cut-off of 1e-6 and HSP length cut-off of 33. Then, an INTERPROSCAN analysis [27] was performed with BLAST2GO default parameters. Finally, the data from BLAST searches, INTERPROSCAN terms, enzyme classification codes (EC), and metabolic pathways (KEGG, Kyoto Encyclopedia of Genes and Genomes) were merged in gene ontology (GO) terms for a wide functional range cover in annotation [26]. The BLAST2GO program defaults were used in all mapping and annotation steps, and the false discovery rate (FDR) cut-off was set to $0.05 \%$ probability level. GO over-representation analysis was performed with BLAST2GO tools with a false discovery rate (FDR) cut-off of $0.05 \%$ probability.

\subsection{Real-time Quantitative Reverse Transcription-Polymerase Chain Reaction (RT-qPCR)}

In order to validate the RNA-seq data and examine the relative contribution of roots and shoots to the transcriptional response, 10 differentially expressed genes (DEGs) with a two-fold change and an FDR $p$-value $<0.05$ were selected for real-time RT-qPCR analysis. Total RNA from roots and shoots was extracted from control and salt-treated samples collected at 1, 24, and $120 \mathrm{~h}$ AT (Figure 1) and used to quantify gene expression in each organ (Figure 2). Elongation Factor1a ( $C q E l F 1 \alpha$ ) was used as the reference gene to normalize and estimate up- or down-regulation of the target genes. Transcript levels are shown as mean normalized expression (MNE). All primers are listed in the supplementary material (Table S1). The expression analysis was performed by Q-gene software, as previously described by Ruiz et al. [8]. Data are means ( \pm standard deviation) of 3 biological replicates.

\subsection{Statistical Analysis}

Two independent experiments were conducted; each experiment comprised 54 individuals, divided into 2 treatments $(0$ and $300 \mathrm{mM} \mathrm{NaCl})$ and 3 collection times $(1,24$, and $120 \mathrm{~h})$ resulting in 9 control and 9 salt-treated plants per time point. These were collected (roots and shoots separately), pooled in 3 groups of 3 individuals (i.e., 3 biological replicates) and processed for RNA extraction. A two-way analysis of variance (ANOVA), followed by a Tukey's post-test, was performed to statistically evaluate significant differences $(p \leq 0.05)$ in root and shoot DW determinations and in the real-time RT-qPCR dataset (InfoStat software [28]). For RNA-seq statistical purposes, we discarded the use of linear models due to the lack of replicates, a crucial factor for dispersion estimation on these methods. Although it is possible to use those methods without replicates, it is not recommended, therefore, we decided to use the Z-test approximation that is designed for such cases.

\section{Results}

\subsection{Phenotype Response and Transcriptome Sequencing}

Although salt-treated individuals exhibited no differences in biomass or plant height compared with controls, leaves of salt-treated plants at $120 \mathrm{~h}$ AT appeared wilted (Figure 3).

The three RNA-seq samples generated approximately 45 to 49 million pairs of short reads, with an average length of $101 \mathrm{bp}$, and a similar quantity of mapped reads that was ca. $72 \%$ of the total read count (Table 1).

Implementing a model based on read counts and using the cut-off value of two-fold change and an FDR $p$-value $<0.05$, identified a total of 2416 DEGs based on the salt-stress treatment and time of sampling (Figure 4). The total number of up-regulated genes in salt-treated vs. control plants at both sampling times was 945, of which 91 were shared, including 13 transcription factors (TFs; Figure 4A, Table 2). The number of up-regulated genes was higher in $300 \mathrm{mM} \mathrm{NaCl}$-treated plants at $120 \mathrm{~h} \mathrm{AT}$ than at $1 \mathrm{~h} \mathrm{AT} \mathrm{(600} \mathrm{and} 436$ contigs, respectively), and this was also reflected in the number of TFs up-regulated in both groups, which increased slightly (Table 2). 

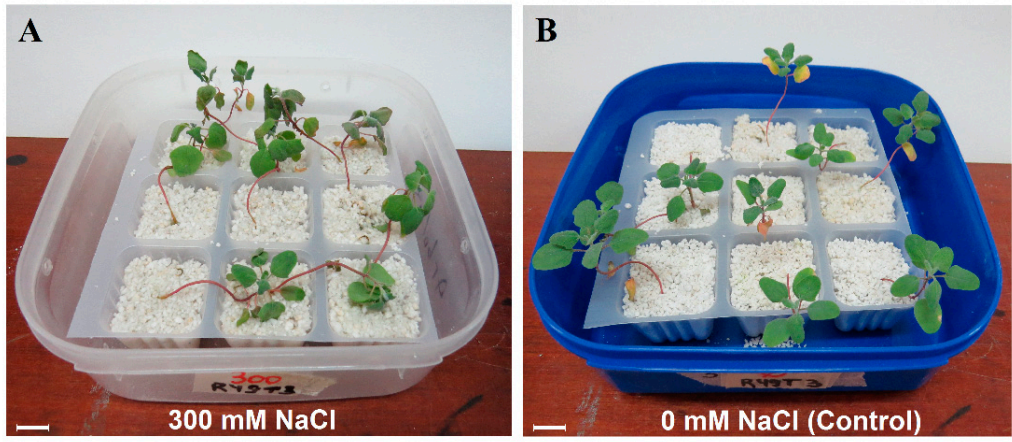

Figure 3. Forty-five-day-old quinoa plants grown in perlite used for RNA-seq and real-time RT-qPCR analyses (A) plants treated with $300 \mathrm{mM} \mathrm{NaCl}$ and (B) controls $(0 \mathrm{mM} \mathrm{NaCl})$. Scale bar $=1 \mathrm{~cm}$.

Table 1. Summary of Chenopodium quinoa, landrace R49 reads mapping against Chenopodium quinoa predicted genes.

\begin{tabular}{cccc}
\hline & \multicolumn{3}{c}{ (Treatment) Time } \\
\hline Total Bases & $\mathbf{( 0 )} \mathbf{~ T 1}$ & $\mathbf{( 3 0 0 )} \mathbf{T} \mathbf{1}$ & $\mathbf{( 3 0 0 )} \mathbf{~ T 3}$ \\
Read Count & $4,971,425,434$ & $4,581,155,576$ & $4,883,948,526$ \\
GC (\%) & $49,222,034$ & $45,357,976$ & $48,355,926$ \\
Average Length (bp) & 43.34 & 43.31 & 43.51 \\
Inputs Reads & 101 & 101 & 101 \\
Mapped Reads & $47,543,290$ & $43,853,712$ & $46,700,950$ \\
Mapped Rate (\%) & $34,220,702$ & $31,442,862$ & $33,862,731$ \\
Q20 (\%) & 71.98 & 71.7 & 72.51 \\
Q30 (\%) & 96.59 & 96.7 & 96.58 \\
\hline
\end{tabular}

Abbreviations: $\mathrm{G}$, guanine; $\mathrm{C}$, cytosine; $\mathrm{Q}$, quality score, a common measure used to assess the accuracy of a sequencing Illumina HiSeq2000 platform.

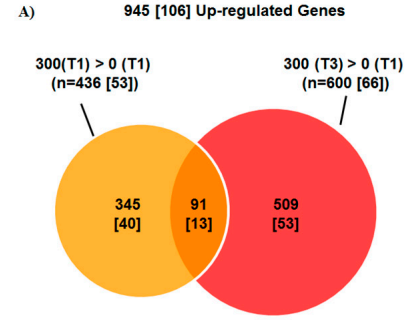

B)

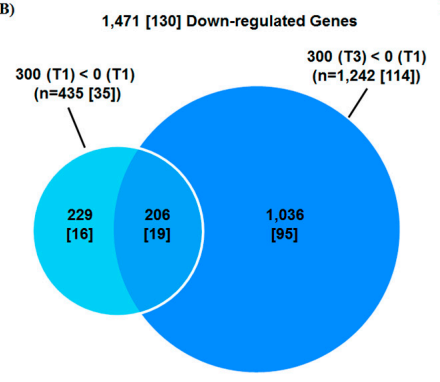

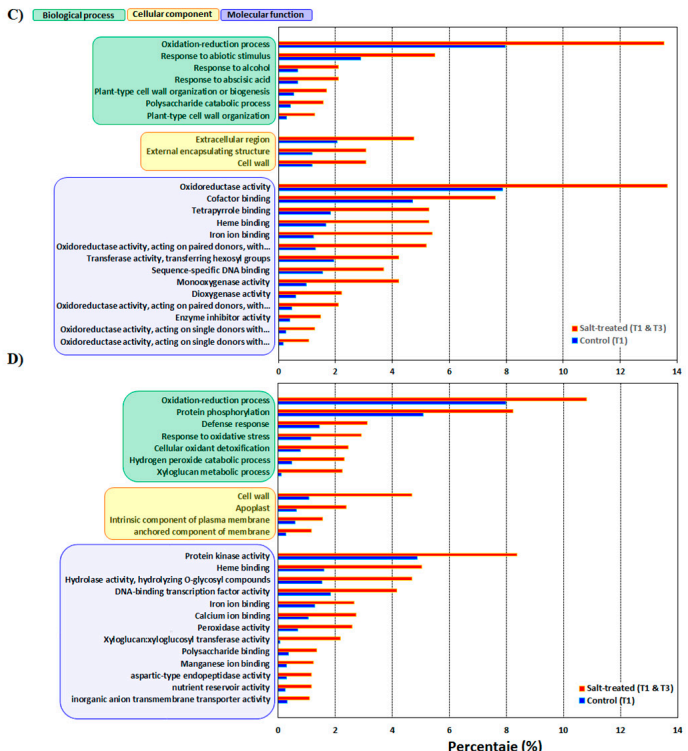

Figure 4. Venn diagrams showing the number of differentially expressed genes (DEGs) $(n=2416)$ in response to $300 \mathrm{mM} \mathrm{NaCl}$ at $1 \mathrm{~h}$ (T1) and $120 \mathrm{~h}$ (T3) after treatment and their overlaps. The number in square brackets indicates the number of genes encoding for transcription factors. (A) Genes induced by salt at $1 \mathrm{~h}$ and $120 \mathrm{~h} \mathrm{AT} \mathrm{(after} \mathrm{treatment)} \mathrm{or} \mathrm{both.} \mathrm{(B)} \mathrm{Genes} \mathrm{down-regulated} \mathrm{by} \mathrm{salt} \mathrm{at} 1 \mathrm{~h}$ and $120 \mathrm{~h}$ AT or both. The size of each group is proportional to the total number of DEGs. (C,D) Functional categories and biological processes of genes that were induced (C) or repressed (D) by $300 \mathrm{mM} \mathrm{NaCl}$ at T1 and/or T3. Red bars: Salt-treated; blue bars: Controls. 
Table 2. Set of selected genes up- or down-regulated by salt treatments at $1 \mathrm{~h}$ and $120 \mathrm{~h}, \mathrm{~T} 1$, and T3, respectively (overlaps in Figure 3).

\begin{tabular}{|c|c|c|c|c|c|c|}
\hline \multirow{3}{*}{ Gene } & \multirow{3}{*}{ Gene Ontology (GO) } & \multirow{3}{*}{ Annotation } & \multicolumn{4}{|c|}{ Kal's Z-test } \\
\hline & & & \multicolumn{2}{|c|}{ 300) $\mathrm{T} 1>(0) \mathrm{T} 1$} & \multicolumn{2}{|c|}{$(300) \mathrm{T} 3>(0) \mathrm{T} 1$} \\
\hline & & & Fold Change & FDR $p$-Value & Fold Change & FDR $p$-Value \\
\hline AUR62029344-RA & GO:0006355 Regulation of transcription, & NAC domain-containing protein 72 & 2.68 & 0.00 & 2.45 & 0.00 \\
\hline AUR62026261-RA & DNA-templated & homeobox-leucine zipper protein HAT5 & 2.90 & 0.00 & 2.49 & 0.00 \\
\hline AUR62021507-RA & & heat stress transcription factor $\mathrm{C}-1$ & 4.06 & 0.00 & 2.50 & 0.00 \\
\hline AUR62004541-RA & & homeobox-leucine zipper protein ATHB-12-like & 4.64 & 0.00 & 5.11 & 0.00 \\
\hline AUR62023642-RA & & ethylene-responsive transcription factor ERF014-like & -3.12 & 0.00 & -4.13 & 0.00 \\
\hline AUR62004723-RA & & ethylene-responsive transcription factor ERF014-like & -2.68 & 0.00 & -3.85 & 0.00 \\
\hline AUR62025525-RA & & ethylene-responsive transcription factor ERF071 & -2.27 & 0.00 & -4.07 & 0.00 \\
\hline AUR62032882-RA & & ethylene-responsive transcription factor ERF021-like & -6.55 & 0.01 & $-\infty$ & 0.00 \\
\hline AUR62032288-RA & GO:0006952 Defense response & acidic chitinase & $-\infty$ & 0.00 & -103.63 & 0.00 \\
\hline AUR62027590-RA & & LRR receptor-like serine/threonine-protein kinase FLS2 & -2.59 & 0.00 & -3.27 & 0.00 \\
\hline AUR62033289-RA & GO:0006950 Response to stress & putative 4-hydroxy-4-methyl-2-oxoglutarate aldolase 3 & 2.79 & 0.00 & 4.93 & 0.00 \\
\hline AUR62037323-RA & & universal stress protein A-like protein & 4.57 & 0.00 & 6.98 & 0.00 \\
\hline AUR62031231-RA & & MLP-like protein 43 & 2.14 & 0.00 & 2.37 & 0.00 \\
\hline AUR62012039-RA & & $18 \mathrm{kDa}$ seed maturation protein-like & 3.82 & 0.01 & 14.18 & 0.00 \\
\hline AUR62021371-RA & & putative 4-hydroxy-4-methyl-2-oxoglutarate aldolase 3 & 4.92 & 0.00 & 4.56 & 0.00 \\
\hline AUR62032222-RA & & inhibitor of trypsin and hageman factor-like & -2.81 & 0.00 & -28.13 & 0.00 \\
\hline AUR62017675-RA & & $\begin{array}{l}\text { chalcone synthase } \\
\text { chas }\end{array}$ & -3.16 & 0.00 & -2.70 & 0.00 \\
\hline AUR62020156-RA & & asparagine synthetase [glutamine-hydrolyzing] & -3.70 & 0.00 & -64.32 & 0.00 \\
\hline AUR62031453-RA & & S-type anion channel SLAH2 isoform X3 & -2.35 & 0.00 & -3.15 & 0.00 \\
\hline AUR62014092-RA & & peroxidase 5 & -2.09 & 0.03 & -6.63 & 0.00 \\
\hline AUR62009744-RA & & peroxidase 57 & -2.67 & 0.00 & -10.86 & 0.00 \\
\hline AUR62030623-RA & GO:0071554 Cell wall & expansin A10 & 4.70 & 0.00 & 2.59 & 0.00 \\
\hline AUR62024921-RA & organization or biogenesis & expansin A10 & 4.93 & 0.00 & 2.90 & 0.00 \\
\hline AUR62002580-RA & & polygalacturonase At1g48100 & 2.60 & 0.00 & 2.37 & 0.00 \\
\hline AUR62018907-RA & & xyloglucan endotransglycosylase/hydrolase & -2.36 & 0.00 & -9.18 & 0.00 \\
\hline AUR62020893-RA & & xyloglucan endotransglucosylase/hydrolase 2-like & -3.08 & 0.00 & -3.77 & 0.00 \\
\hline AUR62024859-RA & & xyloglucan endotransglucosylase/hydrolase protein 22-like & -2.40 & 0.00 & -3.17 & 0.00 \\
\hline AUR62035069-RA & & COBRA-like protein 7 & -2.48 & 0.00 & -2.80 & 0.00 \\
\hline AUR62018602-RA & & expansin-A7-like & -3.07 & 0.05 & -3.78 & 0.01 \\
\hline AUR62018634-RA & & Cellulose synthase-like protein D3 & -2.45 & 0.00 & -3.84 & 0.00 \\
\hline AUR62003130-RA & GO:0009688 Abscisic acid biosynthetic process & nodulin-related protein 1-like & 2.14 & 0.00 & 2.63 & 0.00 \\
\hline AUR62012136-RA & GO:0009737 Response to abscisic acid & protein phosphatase $2 \mathrm{C}$ 37-like & 2.10 & 0.00 & 2.03 & 0.00 \\
\hline AUR62023479-RA & & abscisic acid receptor PYL9 & 3.14 & 0.00 & 2.10 & 0.00 \\
\hline AUR62012310-RA & & abscisic acid receptor PYL4 & -4.31 & 0.00 & -10.00 & 0.00 \\
\hline AUR62010485-RA & & abscisic acid $8^{\prime}$-hydroxylase 1-like & -3.44 & 0.00 & -3.63 & 0.00 \\
\hline AUR62022950-RA & & abscisic acid receptor PYL4 & -2.38 & 0.00 & -11.05 & 0.00 \\
\hline
\end{tabular}

Comparison of DEGs between salt-treated samples up- or down-regulated at a twofold change and false discovery rate (FDR) p-value less than 0.05. Kal's Z-test of proportions was used for the statistical analysis. 
In a total population of 1471 down-regulated genes (Figure 4B), 206 were shared between the two sampling times, including $19 \mathrm{TFs}$, several of which are linked to the ET response pathway (Table 2). The number of down-regulated genes was about three-fold higher in $300 \mathrm{mM} \mathrm{NaCl}$-treated plants at $120 \mathrm{~h}$ AT than at $1 \mathrm{~h}$ AT (1036 and 229 contigs, respectively). This was also reflected in the number of down-regulated TFs that registered a six-fold increase (Table 2).

A subset of 36 DEGs, listed in Table 2, are relevant to several processes linked to regulation of transcription, defense and stress responses, cell wall organization, and ABA metabolism/response. In regards to ET signaling, down-regulation of several Ethylene-Responsive Factor (ERF) genes was detected in response to salt treatment. Up-regulated genes in the "transcriptional regulation" category were those coding for a TF with high similarity to the Arabidopsis NAC domain-containing protein 72, two homeobox-leucine zipper (HAT 5 and ATHB-12-like) proteins, and a heat stress TF (C-1). Moreover, in the "cell wall organization or biogenesis" category, mRNA levels of a polygalacturonase and an expansin (A10) were substantially increased, while several xyloglucan endotransglucosylase genes and an expansin A7-like gene were decreased (Table 2). Salinity also affected the transcription of some stress-related genes; up-regulation of a putative 4-hydroxy-4 methyl-2 oxoglutarate aldolase 3, a universal stress protein A-like protein, MLP-like protein 43, and an 18-kDa seed maturation protein-like, encoding a chaperonin, was observed in salt-treated plants. The expression of genes coding for nodulin-related protein 1-like, a protein phosphatase 2C 37-like, and the ABA receptor PYL9 was stimulated as well. Another evident effect was the transcriptional repression of acidic chitinase and the LRR receptor-like serine/threonine protein kinase FLS2, both of which are involved in defense responses.

\subsection{Functional Annotation and GO}

Results of the functional annotation are shown in Figure 4C,D and File S1. The GO grouped up-regulated genes in three main categories: (1) biological processes, (2) molecular function, and (3) cellular components. A large number of genes that were over-represented under salinity were identified in the biological processes "oxidation-reduction process" and "response to stress" (14\% and 5\%, respectively; Figure $4 \mathrm{C}$ and File S2). Other highly represented biological processes were "response to ABA" (2.5\%) and cell wall organization ("plant-type cell wall organization or biogenesis", "polysaccharide catabolic process", and "plant-type cell wall organization" for a total of $\sim 6 \%$ ). Amongst the down-regulated genes (Figure 4D and File S3), the most enriched subcategory related to biological processes was "oxidation-reduction" ( 11\%) followed by "protein phosphorylation" ( $8 \%)$, "defense response" (3\%), and "response to oxidative stress" (3\%).

In the molecular function category, it was found that ca. $14 \%$ of up-regulated genes were associated with oxidoreductase activity, followed by genes with binding functions to cofactors (7\%), heme groups $(\sim 5 \%)$, and iron (5\%). Analysis of molecular functions that were affected by salinity also showed a large number of genes related to "protein kinase activity" ( $8 \%$ of the down-regulated gene population), while about $18 \%$ of genes were represented in the more general subcategory of "protein binding" that groups heme-, DNA-, TF-, and several types of ion-binding proteins.

Regarding the cellular components category, "cell wall" (4\%), together with "apoplast "( $3 \%)$ were over-represented under salt treatment. Interestingly, "cell wall", "extracellular region", and "external encapsulating structure" were the most represented subcategories in the cellular components' category $(\sim 13 \%)$.

\subsection{RNA-seq Validation by Real-Time RT-qPCR}

To confirm the data obtained by RNA-seq, its assembly, and the analysis made to identify up- and down-regulated genes, the expression of selected DEGs from three different functional categories was assessed by real-time RT-qPCR (information regarding target genes is shown in Table S1). To allow comparisons between RNA-seq and real-time RT-qPCR results, the expression value of a given gene, in both cases, was normalized as the ratio against the expression value of the housekeeping gene ElF1 $\alpha$ (AUR62027947-RA; File S4). 
The expression levels of CarD4 in salt-treated samples at $120 \mathrm{~h}$ AT was two-fold higher than at $1 \mathrm{~h}$ AT and in controls. In this case, both RNA-seq and real-time RT-qPCR results showed the same expression profile (Figure 5A). RD22 transcript amounts increased, but not significantly in salt-treated samples compared to corresponding controls, while the RNA-seq dataset indicated an increase at $120 \mathrm{~h}$ AT (Figure 5B). In both RNA-seq and real-time RT-qPCR datasets, P5CS transcripts showed a similar profile in the three samples, with a significant three-fold increase at $120 \mathrm{~h}$ AT (Figure 5C). LOX also showed a similar expression profile in RNA-seq and real-time RT-qPCR datasets with a significant decrease in salt-treated plants as compared with controls at $120 \mathrm{~h}$ AT (Figure 5D), while LDOX transcript abundance was significantly higher in salt-treated plants collected at $120 \mathrm{~h} \mathrm{AT}$ in both datasets (Figure 5E).

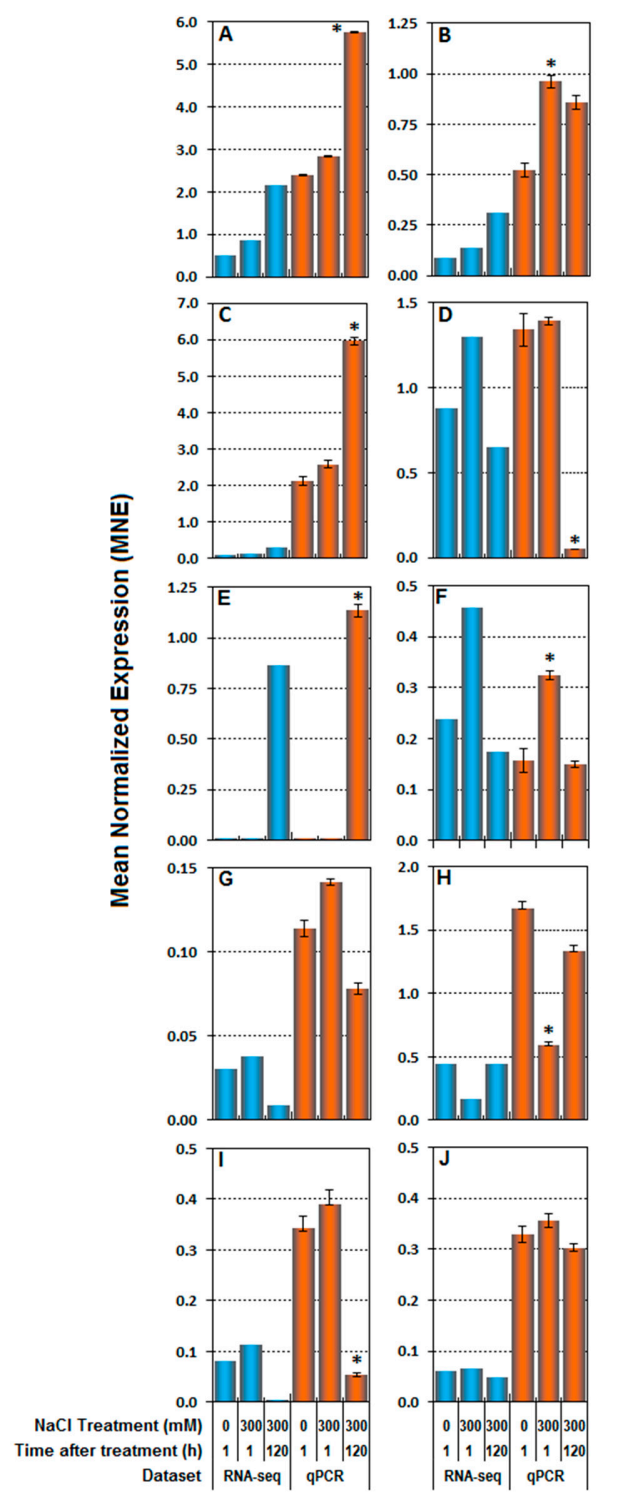

Figure 5. Validation of RNA-seq results by real-time RT-qPCR. The fragments per kilobase per million mapped reads (FPKM) values were calculated from globally normalized RNA-seq data (blue bars). Mean normalized expression (MNE) was obtained by RT-qPCR analysis (orange bars). Both transcript analyses consider 10 genes selected from the RNA-seq dataset to represent different functional categories. Stress-responsive genes: CarD4 (A), RD22 (B), P5CS (C), LOX (D), L-DOX (E); ethylene-related genes: ETR1 (F), ACS1 (G), ACS2 (H), ACO1 (I); growth-related gene: $\beta$-EXP (J). The expression data were normalized to Elongation Factor1 $\alpha$ (CqElF1 $\alpha$ ) and correspond to means of three biological replicates \pm SE. Asterisks indicate significant differences $(p<0.05)$ relative to the control for each set of data. 
We also investigated the ET pathway, which is associated with plant growth and development as well as stress responses. The core of this pathway consisted of two main catalytic enzymes, ACS1 and 2, and $A C O$, together with one gene involved in ET perception (ETR1). ETR1 transcript amount showed similar expression profiles in both datasets, with a significant increased $1 \mathrm{~h}$ AT in the salt-treated samples (Figure 5F). Both ACS1 and ACS2 showed a similar transcript profile in the two datasets; ACS1 mRNA content decreased at $120 \mathrm{~h}$ AT (Figure 5G), whereas ACS2 transcript amount decreased sharply $1 \mathrm{~h}$ AT relative to controls (Figure $5 \mathrm{H}$ ). ACO expression was also significantly down-regulated at $120 \mathrm{~h}$ AT compared to controls in both datasets (Figure 5I).

Finally, transcript content of $\beta$-EXP showed the same trend in both RNA-seq and real-time RT-qPCR analyses, with salinity exerting no significant effects (Figure 5J).

\subsection{Expression Levels in Roots vs. Shoots}

In order to verify the contribution of the single organ to changes in gene expression, real-time RT-qPCR analyses were also performed in roots and shoots separately. The same 10 genes used for the validation of the RNAseq whose transcript levels showed a different expression profile in the RNA-seq analysis, were selected to draw up a heatmap of their time-course changes in MNE under salinity (Figure 6). (1) Stress-related genes: CarD4 was highly expressed in shoots under salinity, with maximum expression occurring late (at 24 and $120 \mathrm{~h} \mathrm{AT}$ ), while in roots, CarD4 transcript content was low and stable over time. The expression profile of $R D 22$ exhibited the highest expression very early after transfer to saline medium, i.e., at 1 and $24 \mathrm{~h}$ AT in roots and shoots, respectively. P5CS was a highly expressed gene, especially at $120 \mathrm{~h}$ in shoots, while in roots, its expression peaked at $24 \mathrm{~h}$ AT. In both tissues, LOX showed a significant down-regulation at $1 \mathrm{~h}$ and $120 \mathrm{~h}$ AT, while a peak of expression was observed at $24 \mathrm{~h}$ AT. L-DOX showed a maximum expression at $120 \mathrm{~h}$ AT in both organs.

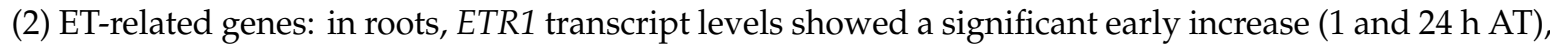
while at $120 \mathrm{~h} \mathrm{AT}$, it returned to control values; in shoots, ETR1 was generally down-regulated. ACS1 transcript content was up-regulated very early ( $1 \mathrm{~h} \mathrm{AT}$ ) in roots, while ACS2 expression was more constant over time in both organs. ACO1 expression increased early ( $1 \mathrm{~h}$ and $24 \mathrm{~h}$ ) in roots after transfer to saline medium; it was significantly down-regulated at $120 \mathrm{~h} \mathrm{AT}$ in both tissues. (3) Growth-related gene: $\beta$-EXP expression was relatively low as compared with other genes and higher in roots than in shoots. The expression of $\beta$-EXP in salt-treated roots was significantly up-regulated only at $1 \mathrm{~h}$ AT; in shoots, its expression was always below or similar to control values at all sampling times.

\begin{tabular}{|c|c|c|c|c|c|c|c|c|c|c|c|c|c|c|c|c|}
\hline \multirow{3}{*}{\multicolumn{2}{|c|}{\begin{tabular}{c|} 
Tissue \\
$\mathrm{NaCl}$ treatment $(\mathrm{mM})$ \\
Time after treatment $(\mathrm{h})$
\end{tabular}}} & \multicolumn{6}{|c|}{$\mathbf{R}$} & \multicolumn{6}{|c|}{$\mathbf{S}$} & \multicolumn{3}{|c|}{$R+S$} \\
\hline & & \multicolumn{3}{|c|}{0} & \multicolumn{3}{|c|}{300} & \multicolumn{3}{|c|}{0} & \multicolumn{3}{|c|}{300} & 0 & \multicolumn{2}{|c|}{300} \\
\hline & & 1 & 24 & 120 & 1 & 24 & 120 & 1 & 24 & 120 & 1 & 24 & 120 & 1 & 1 & 120 \\
\hline CarD4 & \multirow{10}{*}{ 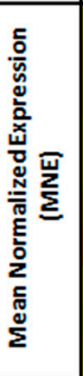 } & & & & & & & & & & * & $*$ & * & & & $*$ \\
\hline$R D 22$ & & & & & $*$ & & $*$ & & & & $*$ & $*$ & & & $*$ & \\
\hline P5CS & & & & & & $*$ & & & & & & & * & & & $*$ \\
\hline LOX & & & & & & $*$ & & & & & $*$ & $*$ & & & & $*$ \\
\hline L-DOX & & & & & & $*$ & $*$ & & & & & & * & & . & $*$ \\
\hline ETR1 & & & & & $*$ & $*$ & & & & & & & & & $*$ & \\
\hline ACS1 & & & & & $*$ & & & & & & & & & & & \\
\hline ACS2 & & & & & & & & & & & $*$ & & & & $*$ & \\
\hline$A C O$ & & & & & $*$ & & $*$ & & & & & $*$ & & & & $*$ \\
\hline$\beta$-EXP & & & & & & & & & & & & & & & & \\
\hline
\end{tabular}

Figure 6. Heatmap representation of the expression profiles (mean normalized expression, MNE) of 10 selected genes after different times $(1,24$, and $120 \mathrm{~h}$ ) of exposure to 0 or $300 \mathrm{mM} \mathrm{NaCl}$. RNA was extracted from roots $(R)$ and shoots $(S)$ separately or pooled prior to cDNA synthesis $(R+S)$. Darker and lighter color shadings represent relatively higher and lower expression levels, respectively. Asterisks indicate significant differences $(p<0.05)$ relative to the control at $1 \mathrm{~h}$. 


\section{Discussion}

\subsection{Salinity Induces Transcriptome-Wide Changes in Quinoa}

The Chilean landrace selected for this study, R49, belongs to the "salares" ecotype. It grows in salt flat regions of the Andean altiplano, at altitudes of 3500-3900 m a.s.1. R49 has a long vegetative phase (ca. 180 days), and it is locally used by quinoa growers due to its high tolerance to frost [29]. Seedling establishment and the early vegetative stage are described as the most sensitive growth phases due to the need for suitable environmental conditions, such as water availability (i.e., seasonal rains), that favor root growth, thus enabling the plant to avoid the high salinity present in the upper soil layers [30,31].

Previously, we showed that, under a prolonged exposure time (45 days), $300 \mathrm{mM} \mathrm{NaCl}$ inhibited root and shoot growth in R49 [17]. In the present work, plants treated with the same concentration of salt did not display significant growth inhibition after 1 week of treatment, even though some visual symptoms of toxicity (wilting) were observed on the leaves. A similar lack of severe growth inhibition was reported in several other quinoa genotypes having a similar origin as R49, i.e., Real and Ollague [9]. In the case of this particular ecotype, its extremely slow growth rate could contribute to better tolerating stress as described by Raney et al. [16] for Ollague exposed to drought conditions. This "trade-off" between growth and resistance was previously observed in a comparison between the "salares" genotype Utusaya and the Danish-bred cv. Titicaca [32].

Sequencing of the quinoa genome [13] combined with three RNA-seq analyses $[9,15,16]$ have increased the availability of genetic information for this halophytic seed-producing crop. The two former reports are on quinoa subjected to drought stress, while the latter considered the reference genome PI614886 [13], belonging to the "coastal" ecotype and originating from Maule (central Chile), under salt stress. Raney et al. [16] identified 462 DEGs in root tissue of Ollague, a Chilean genotype belonging, like R49, to the "salares" ecotype, while Morales et al. [15] found 2456 DEGs after drought stress treatment in combined roots and shoots of R49. In PI614886 subjected to $300 \mathrm{mM} \mathrm{NaCl}$, Schmöckel et al. [9] found a total of 5811 DEGs in roots and shoots (analyzed separately), compared with 2416 DEGs reported in the present study that considers roots and shoots pooled together. Conversely, the number of salt-induced DEGs presently observed is similar to that found by Morales et al. [15] for the same landrace under drought stress.

In several studies, the DEGs reported under salt stress in glycophytes were more abundant than in halophytes [18,33-35]. The lower number of DEGs found by us for R49 ("salares" ecotype) as compared with the less salt-tolerant PI614886 ("coastal" ecotype) suggests that the number of DEGs under salt stress may be inversely proportional to tolerance.

The above-mentioned RNA-seq analyses in quinoa were done only at one time-point (4 days, 7 days, or 4 weeks), while in the present work, we also considered the time factor and, for the first time, investigated the very short-term response ( $1 \mathrm{~h} \mathrm{AT})$. We show here that DEGs increased with exposure time (from $1 \mathrm{~h}$ to $120 \mathrm{~h}$ ) and that down-regulated contigs increased more than the up-regulated ones. Thus, at $120 \mathrm{~h} \mathrm{AT}$, the ratio between up- and down-regulated genes (509 vs. 1036 contigs, respectively) declined by about twice. A similar increase with time in the number of down-regulated genes was observed in Arabidopsis (at 2 vs. $10 \mathrm{~h}$ ) by Matsui et al. [33], by Gong et al. [19] in Arabidopsis and Thelungiella, in chickpea by Mantri et al. [36], in rice by Wang et al. [37] and even in a xerohalophyte, Zygophyllum xanthoxylum [38]. Moreover, several studies reported that salt-tolerant genotypes down-regulate fewer genes than salt-sensitive ones [19,34,38,39]. In quinoa subjected to salt stress for 7 days, Schmöckel et al. [9] reported 622 DEGs in both root and shoot tissues. In this population of shared genes, the down-regulated transcripts were more abundant than up-regulated ones. An opposite pattern was reported in quinoa plants subjected to drought stress [15]. The reason for the increased number of down-regulated genes with increasing exposure time, as presently observed in quinoa under high salinity, could be due to a tight control and efficiency in shutting down the transcriptional process, mainly for those genes associated to oxidative activities and to the cell wall compartment, that could be constitutively turned on. In a comparative study between salt-sensitive 
Arabidopsis and its salt-tolerant relative Thelungiella, Gong et al. [19] showed that some gene clusters were differently regulated under salinity stress. Those that were up-regulated in Arabidopsis but down-regulated in Thellungiella were mainly general defense-related genes and transcription factors, together with genes with protein translation-initiation functions, suggesting that Arabidopsis initiates a global defense response that requires the presence of newly synthesized proteins. They proposed that Thellungiella attempts to conserve resources and energy under stress conditions. Again, this form of "trade-off" may be part of the "halophyte's way" to deal with high salinity.

\subsection{Comprehensive Analysis of DEGs induced by Salt Stress and Biological Insight}

In the present study, a total of 2416 salinity responsive DEGs were identified. These fell into three main categories involving a series of biological processes, mostly linked to oxidation-reduction processes, responses to abiotic stimulus, and protein phosphorylation followed by molecular functions (mainly represented by oxidoreductase activity, cofactor-binding, and protein kinase activity). The cellular components category was mainly enriched in genes related to the extracellular region and cell wall components.

In the same genotype, R49, subjected to drought stress, Morales et al. [15] found that the most represented categories were those related to biological processes, namely primary and organic substance metabolic processes, followed by the category associated to molecular functions, represented by nucleus and plastids. In the cellular component's category, the most enriched subcategories were those related to "organic cyclic and heterocyclic compound binding". In the RNA-seq analysis of Ollague, Raney et al. [16] found that under drought treatment, transferase activity, metal ion binding, cation binding, protein binding, and oxidoreductase activity were the major activities indicated in the molecular function category, while cellular metabolic process, primary metabolic process, response to stress, and response to abiotic stimulus were the major biological processes. In the RNA-seq study with the reference genome PI614886 subjected to salinity stress, Schmöckel et al. [9] found an enrichment of genes involved in catalytic activity, suggesting that the expression of numerous enzymes increases in response to salt. In the present work, a similar pattern of enriched categories was found in R49 under high salinity. Our transcriptomic analysis of R49 also revealed that a large number of DEGs belonged to the biological processes subcategory "oxidation-reduction process". This may confirm previous studies reporting a constitutive high antioxidant level (tocopherols, phenolic compounds, and other compounds with antioxidant activity) in quinoa seeds [4,40,41].

Interestingly, cell wall organization seems to play an important role in R49 salinity responses, as described for garlic [35] and also for the xerohalophyte Zygophyllum xanthoxylum [38]; in response to salt stress, the most enriched subcategories were related to peroxidase activity and lignin formation. In fact, in the categories of biological processes and cellular components, highly represented DEGs were those related to cell wall organization or biogenesis, polysaccharide catabolic process, and cell wall organization together with the extracellular region, apoplast, plasma membrane components, and cell wall-related structures. Indeed, a total of 65 cell wall-related genes were found that were differentially expressed during salt stress, supporting the idea that these may play a crucial role in adaptation to salinity. The cell wall is highly susceptible to salt stress and other biotic and abiotic stresses [42,43]. Salinity usually results in cell wall structure and extensibility alterations as a consequence of changes in levels of lignins, pectins, celluloses, and hemicelluloses [35]. Cell wall extensibility is a vital factor for maintaining normal turgor pressure under salt stress in both salt-sensitive [44,45] and salt-tolerant species [37]. The decline in growth at supra-optimal salinity levels may occur as a result of a decline in turgor [46], consequent upon high concentrations of ions in the apoplast [47], or a change in cell wall elasticity [48].

The expression of some expansin isoforms is correlated with growth, and the external application of expansins can stimulate cell expansion in vivo in several plant systems due to wall loosening [49]. The involvement of expansins in abiotic stress responses has also been documented [50]. Buchanan et al. [51] reported a salinity-induced increase in $\beta$-EXP transcript abundance for Sorghum bicolor. Pitann et al. [52] observed that a $\beta$-expansin protein decreased under salinity in a salt-sensitive maize cultivar, whereas it was less affected in a salt-tolerant one. 
Soon after, Geilfus et al. [53] reported that the maintenance of shoot growth in a salt-resistant variety of maize could be related to an unaffected abundance of $\beta$-expansin proteins. Thus, the stable expression of the $\beta$-EXP gene analyzed here, may be associated with the salt-tolerance of R49. It should be pointed out, however, that the $\beta$-EXP expression pattern observed in the present study was different from that of in vitro-grown seedlings where $\beta$-EXP transcript abundance was salt-induced [8]. This difference likely depends on the experimental system used (agar plates vs. perlite) as well as plant age (12-day vs. 40-day old), a factor that can influence stress responses in quinoa [54].

Several genes associated with biological processes, as identified by the GO analysis, were explored in their expression profile due to their relevance in responses to abiotic stimuli and defense. In particular, five stress-related genes, i.e., $C a r D 4, R D 22, P 5 C S$, LOX, and L-DOX, were selected for real-time RT-qPCR analysis based on changes in the read numbers detected by RNA-seq.

CarD4 transcript levels showed the same pattern in the RNA-seq and real-time RT-qPCR analyses. It was highly expressed only $120 \mathrm{~h}$ AT (Figure 5A) and significantly up-regulated only in shoots (Figure 6). In higher plants, carotenoid cleavage dioxygenases cleave specific carotenoids, thereby producing a diverse set of apocarotenoids. These apocarotenoids are precursors for the production of some plant hormones); they are also responsible for producing volatile aromatic compounds [55] and compounds involved in color and aroma formation in fruits and flowers [56]. In Arabidopsis, 9 CCDs have been classified (CCD1, 4, 7, 8, and NCED2, 3, 5, 6, 9; [57]). CCD7 and 8 were found to be important in the production of strigolactones [58,59], while NCEDs are mainly involved in ABA biosynthesis [60]. The CCD4 family is the largest family of plant CCDs, only present in flowering plants. In saffron, expression of CsCCD4 was significantly induced by dehydration stress and heat treatment [61]. In a further study, $C s C C D 4 c$ was up-regulated by wounding, heat, and osmotic stress, suggesting the involvement of its apocarotenoid products in the adaptation of saffron to environmental stresses [62]. Its up-regulation in salt-stressed R49 suggests that it also plays a critical role in stress adaptation in quinoa.

The stress-related genes RD22 and P5CS were quite similar in their pattern of expression in the RNA-seq and real-time RT-qPCR analyses (Figure 5B,C). P5CS is the key biosynthetic enzyme in the biosynthesis of proline, a well-known osmoprotectant, while RD22 encodes for drought-inducible dehydration responsive protein $[63,64]$. Both transcripts tended to be up-regulated early; however, while P5CS maintained the up-regulation until $120 \mathrm{~h}, R D 22$ returned to control levels. A similar expression profile was observed in our earlier study comparing R49 with Villarrica, a landrace belonging to the "coastal-lowlands" ecotype [8], indicating a differential role for RD22 and P5CS in the longer-term adaptive response of the "salares" landrace.

Lipoxygenases (LOXs) are a special class of dioxygenases that catalyze the conversion of polyunsaturated fatty acids and lipids into oxylipins, such as jasmonic acid and methyl jasmonate, having several roles in defense responses to biotic or abiotic stresses [65]. Our results (Figures 5D and 6) show an early induction of LOX transcript content that declined at the end of the experiment. A similar pattern for CaLOX1 expression in response to high salinity was described in Capsicum annuum where transcription of the gene was induced at $6 \mathrm{~h}$ and gradually declined from 12 to $24 \mathrm{~h}$ after $\mathrm{NaCl}$ treatment $[66,67]$. CaLOX1 was significantly induced in pepper leaves also by bacteria, ethylene, and salicylic acid [66].

The flavonoid biosynthetic pathway is also strongly activated by salinity [68]. Few reports have appeared, however, concerning gene expression and regulation of flavonoid biosynthesis in halophytes and other stress-resistant species. In our transcriptomic study, the gene leucoanthocyanidin dioxygenase (LDOX; Figures 5E and 6) was highly expressed, relatively late (120 h AT), in response to salt stress. $L D O X$ expression is usually regulated to protect plants against damage from UV irradiation and low temperature [69] and also exhibits significant differences in transcript abundance under salt stress [68]. Zhang et al. [70] reported an increase in LDOX transcript levels in Reaumuria trigyna under $500 \mathrm{mM} \mathrm{NaCl}$ treatment. This enhanced expression under salt stress was attributed to unique 
physiological characteristics, and molecular regulatory mechanisms evolved in this species in response to the salinized desert environment in which it has been growing for millions of years.

In many studies on glycophytes, enhanced tolerance to salt stress was shown to be associated with the induction of the ET signaling pathway [71-73]. For instance, increased expression of the ERF transcription factor in wheat and tobacco conferred improved tolerance to salinity $[74,75]$, whereas enhanced oxidative stress was detected in the ethylene-insensitive (ein3-1) mutant of Arabidopsis exposed to salt stress [76]. Yet, the involvement of ET in salinity responses in halophytes has been scarcely characterized [77,78]. As indicated in our real-time RT-qPCR analysis, ETR1, a gene coding for one of the ET receptors, was strongly and rapidly induced in response to salt (Figure 5F). By contrast, the ET biosynthetic genes, ACS1 and ACO, were down-regulated, especially in the long term (Figure 5G,I), while ACS2 was down-regulated only $1 \mathrm{~h}$ AT (Figure $5 \mathrm{H}$ ). Thus, although ETR1 was up-regulated, the ET biosynthesis pathway was substantially down-regulated. This is coherent with the fact that the ET signaling pathway was activated by salt stress, since ETR1, and other ET receptors, are negative regulators of this pathway, i.e., they are activated when they are not bound to ET.

As shown in Figure 6, the salt-induced up-regulation of CarD4 and RD22 observed when roots and shoots $(R+S)$ were analyzed together was mainly due to enhanced transcript abundance in shoots. The enhanced expression level at $120 \mathrm{~h}$ AT of P5CS also occurred mainly in shoots, whereas the up-regulation of $L-D O X$ occurred both in roots and shoots. By contrast, roots accounted for the up-regulation of ETR1 registered in salt-treated plants. A transient increase in ACS1 expression in roots of salt-treated plants was observed, but this was masked in the $\mathrm{R}+\mathrm{S}$ samples by the lack of effect in shoots. The lower, as compared to controls, transcript abundance of $A C O$ in salt-treated plants could be attributed to both organs. Generally speaking, the heat-map shows that stress-related genes were preferentially up-regulated in shoots, while ET-related genes were differentially expressed mainly in the roots and early on after exposure to salt. Most stress-related genes remained switched on up to the end of the experiment. A similar pattern has been described in chickpea treated with salt and drought stresses at different developmental stages [79] and in two cultivars of barley differing in salt stress tolerance [80]. Our time-course analysis of gene expression also revealed a short-term (within $1 \mathrm{~h}$ ) response to salinity for several genes. In fact, the extremely rapid up-or down-regulation of most genes (at 1 or $24 \mathrm{~h}$ ) may be indicative of a pre-adaptive response to salinity in halophytes due to a "constitutive over-expression" of stress-related genes even under non-stressful conditions [18,81]. The expression "stress-anticipatory preparedness" was used by Gong and co-workers [19] in their comparative study on stress tolerance mechanisms in Arabidopsis thaliana and its halophytic relative Thellungiella halophila. More recently, Kazachkova et al. [81] also refer to a "stress ready transcriptome/metabolome" in halophytes. Since quinoa has many ecotypes, varieties, and landraces, further studies are needed to check whether this trait is a generalized phenomenon in this halophytic crop species.

\section{Conclusions}

In this work, we report the first transcriptome analysis of salt-treated quinoa plants of the "salares" genotype R49, which is adapted to a particularly extreme habitat, the altiplano of northern Chile. The analysis revealed a total of 2416 salt-responsive DEGs when roots and shoots were pooled together. These fell into three main categories, namely biological processes (mostly oxidation-reduction processes, responses to abiotic stimulus, and protein phosphorylation) and molecular functions (e.g., oxidoreductase activity, cofactor-binding, and protein kinase activity), while the cellular components category was mainly enriched in genes related to the cell wall. Indeed, 65 cell wall-related DEGs were identified under high salinity, confirming the notion that expansins and other components affecting cell wall properties are involved in abiotic stress tolerance. Amongst the stress-associated genes analyzed by real-time RT-qPCR, differential expression patterns were observed both in a time- and an organ-dependent manner. Some genes (e.g., $R D 22, L O X)$ were rapidly up-regulated and then returned to control levels, while others (e.g., P5CS) remained up-regulated up to $120 \mathrm{~h}$ AT, pointing to the importance of time-course experiments. The involvement of the "stress hormone" ET has, up to 
now, not been investigated in quinoa. We show here, that at least one component of the ET signaling pathway (the ETR1 receptor) was transcriptionally induced by $300 \mathrm{mM} \mathrm{NaCl}$.

Future perspectives: The use of halophytic seed-producing crops to contrast increasing salinization of soil and water sources could contribute to solving the problem of food security in a climate change scenario [82]. Quinoa seems to be a particularly good candidate due to its high adaptability to new agroecosystems, characterized by salty soils and low water and nitrogen availability, and its excellent nutritional properties $[5,6,83]$. The results of this RNA-seq analysis improves our knowledge of the salt-induced transcriptional changes in a quinoa landrace that grows in a very extreme environment, the salt flats of the Andean altiplano. Such knowledge, recorded in the genetic memory of quinoa, will contribute to future breeding efforts, for example, by marker-assisted selection, for quinoa improvement as well as for breeding other crops with increased salt tolerance.

Supplementary Materials: The following are available online at http://www.mdpi.com/2073-4425/10/12/1042/s1, Table S1: List of primers used in this study for real-time RT-qPCR analysis, File S1: Functional annotation of reference transcriptome, File S2: Gene ontology enrichment of functions that belongs to genes over-represented under salinity, File S3: Gene ontology enrichment of functions that belongs to genes down-regulated under salinity, File S4: RNAseq validation by real-time RT-qPCR.

Author Contributions: K.B.R. designed the experiments, produced the plant material, performed the qRT-PCR analyses, analyzed the data; J.M. performed the bioinformatics and statistical analyses; K.B.R. and J.M. prepared the figures; S.B. and H.S. contributed to making available lab instruments and facilities at both institutions; S.B. and H.S. supervised the research and interpreted the data; S.B., J.M. and K.B.R. wrote the article with contributions from all authors.

Funding: This research was supported by CONICYT, FONDECYT/Postdoctoral grant No. 3130624 to Karina B. Ruiz, and by funds (RFO_2015) from the University of Bologna, Italy to Stefania Biondi.

Acknowledgments: The undergraduate student Gonzalo Mena of the Faculty of Agronomical Sciences (Universidad de Chile, Chile) is gratefully acknowledged for assistance in the lab duties. The authors thank Pedro León (Seed Bank, INIA-Vicuña, Chile) for supplying the seeds.

Conflicts of Interest: The authors declare no conflict of interest.

\section{References}

1. Abugoch, L. Chapter 1 Quinoa (Chenopodium quinoa Willd.). Adv. Food Nutr. Res. 2009, 58, 1-31. [CrossRef]

2. Graf, B.L.; Rojas Silva, P.; Rojo, L.E.; Delatorre Herrera, J.; Baldeón, M.E.; Raskin, I. Innovations in health value and functional food development of quinoa (Chenopodium quinoa Willd.). Compr. Rev. Food. Sci. Food Saf 2015, 14, 431-445. [CrossRef] [PubMed]

3. Sun, Y.; Liu, F.; Bendevis, M.; Shabala, S.; Jacobsen, S.E. Sensitivity of two quinoa (Chenopodium quinoa Willd.) varieties to progressive drought stress. J. Agron. Crop Sci. 2014, 200, 12-23. [CrossRef]

4. Ruiz, K.B.; Biondi, S.; Martínez, E.A.; Orsini, F.; Antognoni, F.; Jacobsen, S.E. Quinoa-a model crop for understanding salt-tolerance mechanisms in halophytes. Plant Biosyst. Int. J. Deal. All Asp. Plant Biol. 2016, 150, 357-371. [CrossRef]

5. Ruiz, K.B.; Biondi, S.; Oses, R.; Acuña-Rodríguez, I.S.; Antognoni, F.; Martínez-Mosqueira, E.A.; Coulibaly, A.; Canahua-Murillo, A.; Pinto, M.; Zurita-Silva, A.; et al. Quinoa biodiversity and sustainability for food security under climate change. A review. Agron. Sustain. Dev. 2014, 34, 349-359. [CrossRef]

6. De Ron, A.M.; Sparvoli, F.; Pueyo, J.J.; Bazile, D. Protein crops: Food and feed for the future. Front. Plant Sci. 2017, 8, 105. [CrossRef]

7. Pizarro, R.; Martínez, E. Mercado Real y Potencial de la Quínoa en Chile. Tierra Adentro-Edición Especial 2015, 108, 74-78. Available online: http://biblioteca.inia.cl/medios/biblioteca/ta/TA108.pdf (accessed on 7 December 2019).

8. Ruiz, K.B.; Rapparini, F.; Bertazza, G.; Silva, H.; Torrigiani, P.; Biondi, S. Comparing salt-induced responses at the transcript level in a salares and coastal-lowlands landrace of quinoa (Chenopodium quinoa Willd). Environ. Exp. Bot. 2017, 139, 127-142. [CrossRef]

9. Schmöckel, S.M.; Lightfoot, D.J.; Razali, R.; Tester, M.; Jarvis, D.E. Identification of putative transmembrane proteins Involved in Salinity Tolerance in Chenopodium quinoa by Integrating Physiological Data, RNAseq, and SNP Analyses. Front. Plant Sci. 2017, 8, 1023. [CrossRef] 
10. Maughan, P.J.; Turner, T.B.; Coleman, C.E.; Elzinga, D.B.; Jellen, E.N.; Morales, J.A.; Udall, J.A.; Fairbanks, D.J.; Bonifacio, A. Characterization of Salt overly sensitive 1 (SOS1) gene homoeologs in quinoa (Chenopodium quinoa Willd.). Genome 2009, 52, 647-657. [CrossRef]

11. Ruiz-Carrasco, K.; Antognoni, F.; Coulibaly, A.K.; Lizardi, S.; Covarrubias, A.; Martinez, E.A.; Molina-Montenegro, M.A.; Biondi, S.; Zurita-Silva, A. Variation in salinity tolerance of four lowland genotypes of quinoa (Chenopodium quinoa Willd.) as assessed by growth, physiological traits, and sodium transporter gene expression. Plant Physiol. Biochem. 2011, 49, 1333-1341. [CrossRef] [PubMed]

12. Yasui, Y.; Hirakawa, H.; Oikawa, T.; Toyoshima, M.; Matsuzaki, C.; Ueno, M.; Mizuno, N.; Nagatoshi, Y.; Imamura, T.; Miyago, M.; et al. Draft genome sequence of an inbred line of Chenopodium quinoa, an allotetraploid crop with great environmental adaptability and outstanding nutritional properties. DNA Res. 2016, 23, 535-546. [CrossRef] [PubMed]

13. Jarvis, D.E.; Ho, Y.S.; Lightfoot, D.J.; Schmöckel, S.M.; Li, B.; Borm, T.J.; Ohyanagi, H.; Mineta, K.; Michell, C.T.; Saber, N.; et al. The genome of Chenopodium quinoa. Nature 2017, 542, 307-312. [CrossRef] [PubMed]

14. Bazile, D.; Thomet, M. El aporte de las comunidades indígenas y locales a la conservación de la quínoa. Tierra Adentro 2015, 108, 22-27.

15. Morales, A.; Zurita-Silva, A.; Maldonado, J.; Silva, H. Transcriptional responses of Chilean quinoa (Chenopodium quinoa Willd.) under water deficit conditions uncovers ABA-independent expression patterns. Front. Plant Sci. 2017, 8, 216. [CrossRef]

16. Raney, J.; Reynolds, D.; Elzinga, D.; Page, J.; Udall, J.A.; Jellen, E.N.; Bonfacio, A.; Fairbanks, D.J.; Maughan, P.J. Transcriptome analysis of drought induced stress in Chenopodium quinoa. Am. J. Plant Sci. 2014, 5, 338-357. [CrossRef]

17. Ruiz, K.B.; Aloisi, I.; Del Duca, S.; Canelo, V.; Torrigiani, P.; Silva, H.; Biondi, S. Salares versus coastal ecotypes of quinoa: Salinity responses in Chilean landraces from contrasting habitats. Plant Physiol. Biochem. 2016, 101, 1-13. [CrossRef]

18. Taji, T.; Seki, M.; Satou, M.; Sakurai, T.; Kobayashi, M.; Ishiyama, K.; Narusaka, Y.; Narusaka, M.; Zhu, J.K.; Shinozaki, K. Comparative genomics in salt tolerance between Arabidopsis and Arabidopsis-related halophyte salt cress using Arabidopsis microarray. Plant Physiol. 2004, 135, 1697-1709. [CrossRef]

19. Gong, Q.; Li, P.; Ma, S.; Indu Rupassara, S.; Bohnert, H.J. Salinity stress adaptation competence in the extremophile Thellungiella halophila in comparison with its relative Arabidopsis thaliana. Plant J. 2005, 44, 826-839. [CrossRef]

20. Himabundi, Y.; Chakradhar, T.; Reddy, M.C.; Kanygin, A.; Redding, K.E.; Chandrasekhar, T. Salt-tolerant genes from halophytes are potential key players of salt tolerance in glycophytes. Environ. Exp. Bot. 2016, 124, 39-63. [CrossRef]

21. Chang, S.; Puryear, J.; Cairney, J.A. Simple and efficient method for isolating RNA from pine trees. Plant Mol. Biol. Rep. 1993, 11, 113-116. [CrossRef]

22. Kal, A.J.; van Zonneveld, A.J.; Benes, V.; van den Berg, M.; Koerkamp, M.G.; Albermann, K.; Strack, N.; Ruijter, J.M.; Richter, A.; Dujon, B.; et al. Dynamics of gene expression revealed by comparison of serial analysis of gene expression transcript profiles from yeast grown on two different carbon sources. Mol. Biol. Cell 1999, 10, 1859-1872. [CrossRef] [PubMed]

23. Hansen, K.D.; Irizarry, R.A.; Wu, Z. Removing technical variability in RNA-seq data using conditional quantile normalization. Biostatistics 2012, 13, 204-216. [CrossRef] [PubMed]

24. Dillies, M.A.; Rau, A.; Aubert, J.; Hennequet-Antier, C.; Jeanmougin, M.; Servant, N.; Keime, C.; Marot, G.; Castel, D.; Estelle, J.; et al. A comprehensive evaluation of normalization methods for Illumina high-throughput RNA sequencing data analysis. Brief. Bioinform. 2013, 14, 671-683. [CrossRef]

25. Conesa, A.; Gotz, S. Blast2GO: A comprehensive suite for functional analysis in plant genomics. Int. J. Plant Genom. 2008, 2008, 619832. [CrossRef]

26. Altschul, S.F.; Gish, W.; Miller, W.; Myers, E.W.; Lipman, D.J. Basic local alignment search tool. J. Mol. Biol. 1990, 215, 403-410. [CrossRef]

27. Hunter, S.; Apweiler, R.; Attwood, T.K.; Bairoch, A.; Bateman, A.; Binns, D.; Bork, P.; Das, U.; Daugherty, L.; Duquenne, L.; et al. InterPro: The integrative protein signature database. Nucleic Acids Res. 2009, 37, D211-D215. [CrossRef] 
28. Di Rienzo, J.A.; Casanoves, F.; Balzarini, M.G.; Gonzalez, L.; Tablada, M.; Robledo, C.W. InfoStat versión Grupo InfoStat; FCA; Universidad Nacional de Córdoba: Argentina, South America, 2015; Available online: http://www.infostat.com.ar (accessed on 7 December 2019).

29. Delatorre, J.; Salinas, A.; Sánchez, M. Revista Agricultura Del Desierto; Cultivo de la Quinua: Iquique, Chile, 2008; p. 111. ISSN 0717-2769.

30. García, M.; Raes, D.; Jacobsen, S.E.; Michel, T. Agroclimatic constraints for rainfed agriculture in the Bolivian altiplano. J. Arid. Environ. 2007, 71, 109-121. [CrossRef]

31. Gandarillas, A.; Saravia, R.; Plata, G.; Quispe, R.; Ortiz-Romero, R. Quinoa in Chile. In State of the Art Report of Quinoa in the World in 2013; Bazile, D., Bertero, H.D., Nieto, C., Eds.; FAO and CIRAD: Rome, Italy, 2015; pp. 401-421. ISBN 978-92-5-108558-5.

32. Adolf, V.I.; Shabala, S.; Andersen, M.N.; Razzaghi, F.; Jacobsen, S.E. Varietal differences of quinoa's tolerance to saline conditions. Plant Soil 2012, 357, 117-129. [CrossRef]

33. Matsui, A.; Ishida, J.; Morosawa, T.; Mochizuki, Y.; Kaminuma, E.; Endo, T.A.; Okamoto, M.; Nambara, E.; Nakajima, M.; Kawashima, M. Arabidopsis transcriptome analysis under drought, cold, high-salinity and ABA treatment conditions using a tiling array. Plant Cell Physiol. 2008, 49, 1135-1149. [CrossRef]

34. Lei, Y.; Xu, Y.; Hettenhausen, C.; Lu, C.; Shen, G.; Zhang, C.; Li, J.; Song, J.; Lin, H.; Wu, J. Comparative analysis of alfalfa (Medicago sativa L.) leaf transcriptomes reveals genotype-specific salt tolerance mechanisms. BMC Plant Biol. 2018, 18, 35. [CrossRef] [PubMed]

35. Wang, G.L.; Ren, X.Q.; Liu, J.X.; Yang, F.; Wang, Y.P.; Xiong, A.S. Transcript profiling reveals an important role of cell wall remodeling and hormone signaling under salt stress in garlic. Plant Physiol. Biochem. 2019, 135, 87-98. [CrossRef] [PubMed]

36. Mantri, N.L.; Ford, R.; Coram, T.E.; Pang, E.C. Transcriptional profiling of chickpea genes differentially regulated in response to high-salinity, cold and drought. BMC Genom. 2007, 8, 303. [CrossRef] [PubMed]

37. Wang, W.S.; Zhao, X.Q.; Li, M.; Huang, L.Y.; Xu, J.L.; Zhang, F.; Cui, Y.R.; Fu, B.Y.; Li, Z.K. Complex molecular mechanisms underlying seedling salt tolerance in rice revealed by comparative transcriptome and metabolomic profiling. J. Exp. Bot. 2015, 67, 405-419. [CrossRef] [PubMed]

38. Chai, W.W.; Wang, W.Y.; Ma, Q.; Yin, H.J.; Hepworth, S.; Wang, S.M. Comparative transcriptome analysis reveals unique genetic adaptations conferring salt tolerance in a xerohalophyte. Funct. Plant Biol. 2019, 46, 670-683. [CrossRef] [PubMed]

39. Peng, Z.; He, S.; Gong, W.; Sun, J.; Pan, Z.; Xu, F.; Lu, Y.; Du, X. Comprehensive analysis of differentially expressed genes and transcriptional regulation induced by salt stress in two contrasting cotton genotypes. BMC Genom. 2014, 15, 760. [CrossRef]

40. Antognoni, F.; Faudale, M.; Poli, F.; Biondi, S. Methyl jasmonate differentially affects tocopherol content and tyrosine amino transferase activity in cultured cells of Amaranthus caudatus and Chenopodium quinoa. Plant Biol. 2009, 11, 161-169. [CrossRef]

41. Aloisi, I.; Parrotta, L.; Ruiz, K.B.; Landi, C.; Bini, L.; Cai, G.; Biondi, S.; Del Duca, S. New insight into quinoa seed quality under salinity: Changes in proteomic and amino acid profiles, phenolic content, and antioxidant activity of protein extracts. Front. Plant Sci. 2016, 7, 656. [CrossRef]

42. Yang, J.; Yen, H.E. Early salt stress effects on the changes in chemical composition in leaves of ice plant and Arabidopsis. A Fourier transform infrared spectroscopy study. Plant Physiol. 2002, 130, 1032-1042. [CrossRef]

43. Le Gall, H.; Philippe, F.; Domon, J.M.; Gillet, F.; Pelloux, J.; Rayon, C. Cell wall metabolism in response to abiotic stress. Plants 2015, 4, 112-166. [CrossRef]

44. Li, H.; Yan, S.; Zhao, L.; Tan, J.; Zhang, Q.; Gao, F.; Wang, P.; Hou, H.; Li, L. Histone acetylation associated up-regulation of the cell wall related genes is involved in salt stress induced maize root swelling. BMC Plant Biol. 2014, 14, 105. [CrossRef] [PubMed]

45. Shen, X.; Wang, Z.; Song, X.; Xu, J.; Jiang, C.; Zhao, Y.; Ma, C.; Zhang, H. Transcriptomic profiling revealed an important role of cell wall remodeling and ethylene signaling pathway during salt acclimation in Arabidopsis. Plant Mol. Biol. 2014, 86, 303-317. [CrossRef] [PubMed]

46. Rozema, J. Growth, water and ion relationships of halophytic monocotyledonae and dicotyledonae; a unified concept. Aquat. Bot. 1991, 39, 17-33. [CrossRef]

47. James, R.A.; Munns, R.; Von Caemmerer, S.; Trejo, C.; Miller, C.; Condon, T. Photosynthetic capacity is related to the cellular and subcellular partitioning of $\mathrm{Na}^{+}, \mathrm{K}^{+}$and $\mathrm{Cl}^{-}$in salt-affected barley and durum wheat. Plant Cell Environ. 2006, 29, 2185-2197. [CrossRef] 
48. Touchette, B.W. Seagrass-salinity interactions: Physiological mechanisms used by submersed marine angiosperms for a life at sea. J. Exp. Mar. Biol. Ecol. 2007, 350, 194-215. [CrossRef]

49. Cosgrove, D.J. Loosening of plant cell walls by expansins. Nature 2000, 407, 321-326. [CrossRef]

50. Chen, Y.; Zhang, B.; Li, C.; Lei, C.; Kong, C.; Yang, Y.; Gong, M. A comprehensive expression analysis of the expansin gene family in potato (Solanum tuberosum) discloses stress-responsive expansin-like B genes for drought and heat tolerances. PLoS ONE 2019, 14, e0219837. [CrossRef]

51. Buchanan, C.D.; Lim, S.; Salzman, R.A.; Kagiampakis, I.; Morishige, D.T.; Weers, B.D. Sorghum bicolor's transcriptome response to dehydration, high salinity and ABA. Plant Mol. Biol. 2005, 58, 699-720. [CrossRef]

52. Pitann, B.; Zörb, C.; Mühling, K.H. Comparative proteome analysis of maize (Zea mays L.) expansins under salinity. J. Plant Nutr. Soil Sci. 2009, 172, 75-77. [CrossRef]

53. Geilfus, C.M.; Zörb, C.; Mühling, K.H. Salt stress differentially affects growth-mediating $\beta$-expansins in resistant and sensitive maize (Zea mays L.). Plant Physiol. Biochem. 2010, 48, 993-998. [CrossRef]

54. Adolf, V.I.; Jacobsen, S.E.; Shabala, S. Salt tolerance mechanisms in quinoa (Chenopodium quinoa Willd.). Environ. Exp. Bot. 2013, 92, 43-54. [CrossRef]

55. Brandi, F.; Bar, E.; Mourgues, F.; Horvath, G.; Turcsi, E.; Giuliano, G.; Liverani, A.; Tartarini, S.; Lewinsohn, E.; Rosati, C. Study of 'Redhaven' peach and its white-fleshed mutant suggests a key role of CCD4 carotenoid dioxygenase in carotenoid and nor-isoprenoid volatile metabolism. BMC Plant Biol. 2011, 11, 24. [CrossRef] [PubMed]

56. Ohmiya, A.; Kishimoto, S.; Aida, R.; Yoshioka, S.; Sumitomo, K. Carotenoid cleavage dioxygenase (CmCCD4a) contributes to white color formation in Chrysanthemum petals. Plant Physiol. 2006, 142, 1193-1201. [CrossRef] [PubMed]

57. Huang, F.C.; Molnár, P.; Schwab, W. Cloning and functional characterization of carotenoid cleavage dioxygenase 4 genes. J. Exp. Bot. 2009, 60, 3011-3022. [CrossRef]

58. Walter, M.H.; Strack, D. Carotenoids and their cleavage products: Biosynthesis and functions. Nat. Prod. Rep. 2011, 28, 663-692. [CrossRef]

59. Zheng, X.; Xie, Z.; Zhu, K.; Xu, Q.; Deng, X.; Pan, Z. Isolation and characterization of carotenoid cleavage dioxygenase 4 genes from different citrus species. Mol. Genet. Genom. 2015, 290, 1589-1603. [CrossRef]

60. Tan, B.C.; Joseph, L.M.; Deng, W.T.; Liu, L.; Li, Q.B.; Cline, K.; McCarty, D.R. Molecular characterization of the Arabidopsis 9-cis epoxycarotenoid dioxygenase gene family. Plant J. 2003, 35, 44-56. [CrossRef]

61. Rubio, A.; Rambla, J.L.; Santaella, M.; Gómez, M.D.; Orzaez, D.; Granell, A.; Gómez-Gómez, L. Cytosolic and plastoglobule-targeted carotenoid dioxygenases from Crocus sativus are both involved in beta-ionone release. J. Biol. Chem. 2008, 283, 24816-24825. [CrossRef]

62. Rubio-Moraga, A.; Rambla, J.L.; Fernández-de-Carmen, A.; Trapero-Mozos, A.; Ahrazem, O.; Orzáez, D.; Granell, A.; Gómez-Gómez, L. New target carotenoids for CCD4 enzymes are revealed with the characterization of a novel stress-induced carotenoid cleavage dioxygenase gene from Crocus sativus. Plant Mol. Biol. 2014, 86, 555-569. [CrossRef]

63. Hanana, M.; Deluc, L.; Fouquet, R.; Daldoul, S.; Leon, C.; Barrieu, F.; Ghorbel, A.; Mliki, A.; Hamdi, S. Identification and characterization of " $r d 22$ " dehydration responsive gene in grapevine (Vitis vinifera L.). Compets R Biol. 2008, 331, 569-578. [CrossRef]

64. Nakashima, K.; Yamaguchi-Shinozaki, K.; Shinozaki, K. The transcriptional regulatory network in the drought response and its crosstalk in abiotic stress responses including drought, cold, and heat. Front. Plant Sci. 2014, 5, 170. [CrossRef] [PubMed]

65. Acosta, I.F.; Farmer, E.E. Jasmonates. In Arabidopsis Book; American Society of Plant Biologist, BioOne Complete: Washington, DC, USA, 2010; Available online: https://doi.org/10.1199/tab.0129 (accessed on 7 December 2019).

66. Hwang, I.S.; Hwang, B.K. The pepper 9-lipoxygenase gene CaLOX1 functions in defense and cell death responses to microbial pathogens. Plant Physiol. 2010, 152, 948-967. [CrossRef] [PubMed]

67. Lim, C.W.; Han, S.W.; Hwang, I.S.; Kim, D.S.; Hwang, B.K.; Lee, S.C. The pepper lipoxygenase CaLOX1 plays a role in osmotic, drought and high salinity stress response. Plant Cell Physiol. 2015, 56, 930-942. [CrossRef] [PubMed]

68. Dang, Z.H.; Zheng, L.L.; Wang, J.; Gao, Z.; Wu, S.B.; Qi, Z.; Wang, Y.C. Transcriptomic profiling of the salt-stress response in the wild recretohalophyte Reaumuria trigyna. BMC Genom. 2013, 14, 397-402. [CrossRef]

69. Berli, F.J; Fanzone, M.; Piccoli, P.; Bottini, R. Solar UV-B and ABA are involved in phenol metabolism of Vitis vinifera L. increasing biosynthesis of berry skin polyphenols. J. Agric. Food Chem. 2011, 59, 4874-4884. [CrossRef] 
70. Zhang, H.; Du, C.; Wang, Y.; Wang, J.; Zheng, L.; Wang, Y. The Reaumuria trigyna leucoanthocyanidin dioxygenase $(R t L D O X)$ gene complements anthocyanidin synthesis and increases the salt tolerance potential of a transgenic Arabidopsis LDOX mutant. Plant Physiol. Biochem. 2016, 106, 278-287. [CrossRef]

71. Dou, L.; He, K.; Higaki, T.; Wang, X.; Mao, T. Ethylene signaling modulates cortical microtubule reassembly in response to salt stress. Plant Physiol. 2018, 176, 2071-2081. [CrossRef]

72. Prerostova, S.; Dobrev, P.I.; Gaudinova, A.; Hosek, P.; Soudek, P.; Knirsch, V.; Vankova, R. Hormonal dynamics during salt stress responses of salt-sensitive Arabidopsis thaliana and salt-tolerant Thellungiella salsuginea. Plant Sci. 2017, 264, 188-198. [CrossRef]

73. Zhang, M.; Smith, J.; Harberd, N.P.; Jiang, C. The regulatory roles of ethylene and reactive oxygen species (ROS) in plant salt stress responses. Plant Mol. Biol. 2016, 91, 651-659. [CrossRef]

74. Rong, W.; Qi, L.; Wang, A.; Ye, X.; Du, L.; Liang, H.; Xin, Z.; Zhang, Z. The ERF transcription factor TaERF3 promotes tolerance to salt and drought stresses in wheat. Plant Biotechnol. J. 2014, 12, 468-479. [CrossRef]

75. Wu, D.; Ji, J.; Wang, G.; Guan, C.; Jin, C. LchERF, a novel ethylene-responsive transcription factor from Lycium chinense, confers salt tolerance in transgenic tobacco. Plant Cell Rep. 2014, 33, 2033-2045. [CrossRef]

76. Asensi-Fabado, M.A.; Cela, J.; Müller, M.; Arrom, L.; Chang, C.; Munné-Bosch, S. Enhanced oxidative stress in the ethylene-insensitive (ein3-1) mutant of Arabidopsis thaliana exposed to salt stress. J. Plant Physiol. 2012, 169, 360-368. [CrossRef]

77. Nikalje, G.D.; Nikam, T.; Suprasanna, P. Looking at halophytic adaptation to high salinity through genomics landscape. Curr. Genom. 2017, 18, 542-552. [CrossRef]

78. Gharbi, E.; Martínez, J.P.; Benahmed, H.; Fauconnier, M.L.; Lutts, S.; Quinet, M. Salicylic acid differently impacts ethylene and polyamine synthesis in the glycophyte Solanum lycopersicum and the wild-related halophyte Solanum chilense exposed to mild salt stress. Physiol. Plant 2016, 158, 152-167. [CrossRef]

79. Garg, R.; Shankar, R.; Thakkar, B.; Kudapa, H.; Krishnamurthy, L.; Mantri, N.; Varshney, R.K.; Bhatia, S.; Jain, M. Transcriptome analyses reveal genotype- and developmental stage-specific molecular responses to drought and salinity stresses in chickpea. Sci. Rep. 2016, 6, 19228. [CrossRef]

80. Patterson, J.H.; Newbigin, E.D.; Tester, M.; Bacic, A.; Roessner, U. Metabolic responses to salt stress of barley (Hordeum vulgare L.) cultivars, Sahara and Clipper, which differ in salinity tolerance. J. Exp. Bot. 2009, 60, 4089-4103. [CrossRef]

81. Kazachkova, Y.; Eshel, G.; Pantha, P.; Cheeseman, J.M.; Dassanayake, M.; Barak, S. Halophytism: What have we learnt from Arabidopsis thaliana relative model systems? Plant Physiol. 2018, 178, 972-988. [CrossRef]

82. Cheeseman, J. Food Security in the Face of Salinity, Drought, Climate Change, and Population Growth. In Halophytes for Food Security in Dry Lands; Khan, M.A., Ozturk, M., Gul, B., Ahmed, M.Z., Eds.; Academic Press, Nikki Levy: Waltham, MA, USA, 2016; ISBN 9780128018545.

83. Bascuñán-Godoy, L.; Sanhueza, C.; Pinto, K.; Cifuentes, L.; Reguera, M.; Briones, V.; Zurita-Silva, A.; Álvarez, R.; Morales, A.; Silva, H. Nitrogen physiology of contrasting genotypes of Chenopodium quinoa Willd. (Amaranthaceae). Sci. Rep. 2018, 8, 17524. [CrossRef]

(C) 2019 by the authors. Licensee MDPI, Basel, Switzerland. This article is an open access article distributed under the terms and conditions of the Creative Commons Attribution (CC BY) license (http://creativecommons.org/licenses/by/4.0/). 